\title{
Proposal of a new nomenclature for the underlying pathogenetic mechanism of severe Coronavirus Disease-19: "Inflammatory Thrombosis with Immune Endotheliitis-ITIE"
}

\author{
Emre Bilgin $^{1}\left[\right.$ [ $\cdot$ Ali ihsan Ertenli ${ }^{1}$ (I)
}

Received: 12 November 2020 / Accepted: 2 December 2020 / Published online: 3 January 2021

(c) The Author(s), under exclusive licence to Springer-Verlag GmbH, DE part of Springer Nature 2021

\section{Dear Editor,}

The world is going through an extraordinary period. Science is evolving very rapidly as never seen on planet Earth. Severe acute respiratory syndrome-coronavirus-2 (SARS-CoV-2) is the causing agent of this pandemic, and the disease caused by this virus is called coronavirus disease-19 (COVID-19). Clinical spectrum of COVID-19 is very wide: ranging from asymptomatic patients to hyperimmune activation with or without apparant thrombosis. About $15-20 \%$ of the cases develop moderate-to-severe manifestations and about $5 \%$ of all patients admit to critical care unit [1]. Herein, we tried to propose a new nomenclature for the pathophysiological process going on the patients resembling severe COVID-19.

The underlying mechanism of severe disease has been proposed as "the activation of the immune system". At the early stages of pandemic, "hyper-inflammation" caused by SARS-CoV-2 has been thought as a kind of "macrophage activation syndrome (MAS)". However, growing body of data is now supporting that the process triggered by SARSCoV-2 differs from classical MAS. First, main histopathological feature causing organ dysfunction in COVID-19 is the thrombosis which is quite rare in classical MAS [2]. A recent review of the main histopathological findings of COVID-19 revealed thrombus formation (either macro or micro) nearly in all tissues, especially in the lung and central nervous system [3]. Second, laboratory parameters are somehow different in COVID-19-related hyper-inflammation than classical MAS. For instance, ferritin level is extremely high in classical MAS compared to relatively high levels in COVID-19-related hyper-inflammation. Fibrinogen

Ali İhsan Ertenli

iertenli@hacettepe.edu.tr

1 Division of Rheumatology, Department of Internal Medicine, Hacettepe University Faculty of Medicine, Ankara, Turkey level is low in classical MAS suggesting the development of disseminated intravascular coagulation (DIC); however, fibrinogen level is extremely high in COVID-19-related hyper-inflammation, supporting the hypothesis of pulmonary intravascular coagulopathy is prominant in COVID-19 patients rather than DIC [4].

Laboratory surrogate of possible thrombotic process (D-Dimer) is also extremely high in COVID-19-related hyper-inflammation state in contrast to classical MAS [5]. "Cytokine release syndrome (CRS)" was another proposed term for the process occurred in COVID-19. However, cytokine profile and laboratory values are somehow different in two entities. Ferritin, interleukin-6 and soluble interleukin-2 receptor-alpha levels are extremely higher in CRS compared to COVID-19-related hyper-inflammation [5]. On the other hand; d-dimer and fibrinogen levels are extremely higher in COVID-19-related hyper-inflammation compared to CRS [5]. Another overlapping but differing situation is the typical acute respiratory distress syndrome (ARDS), and in ARDS, cytokine levels, IL-6,8 and tumor necrosis alpha, are extremely high compared to COVID-19-related hyperinflammation [6]. Also, necropathological examination of patient with COVID-19 revealed a much higher rate of microvascular injury and microthrombi compared to ARDS related to other infections, and accelerated thrombosis plays a central role in COVID-19 [7, 8]. Besides the cytokine and laboratory parameter differences between COVID-19 and other clinical entities, pulmonary endothelialitis plays a central role in COVID-19. Endotheliitis leads to disruption of vascular integrity and remaining subendothelial substances activate coagulation cascade; VEGF-A, PDGF-AA, PDGF$\mathrm{AB} / \mathrm{BB}$, angiopoietin-2, FLT-3L and PAI-1 are several biomoleculs proposed as a biomarker for endotheliitis $[9,10]$. This injury may explain the microthrombi formation and elevation of D-dimer. Also, another clue of the endotheliitis and its involvement in the COVID-19 is the high prevalence of Kawasaki disease in children. 
Current nomenclature of the process occuring in COVID19 is highly confusing. In clinical aspect, "inflammation"oriented definitions have promoted anti-cytokine-based treatments and have left aside the treatments targeting coagulation process. However, none of the anti-cytokine-based treatments have been shown to reduce mortality, yet.

Regarding all these data, we are proposing a new name for the COVID-19-related hyper-inflammation "Inflammatory thrombosis with immune endotheliitis [ITIE]" that implicates the underlying process more clearly and combines the pathways that should be targeted with medical therapies.

Funding None.

\section{Compliance with ethical standards}

Conflict of interest None.

\section{References}

1. Li LQ, Huang T, Wang YQ, Wang ZP, Liang Y, Huang TB, Zhang HY, Sun W, Wang Y (2020) COVID-19 patients' clinical characteristics, discharge rate, and fatality rate of meta-analysis. J Med Virol 92(6):577-583. https://doi.org/10.1002/jmv.25757

2. Minoia F, Tibaldi J, Muratore V, Gallizzi R, Bracaglia C, Arduini A, Comak E, Vougiouka O, Trauzeddel R, Filocamo G, Micalizzi C, Kasapcopur O, Unsal E, Kitoh T, Tsitsamis E, Kostik MC, Ron R, Pachlopnik J, Maritsi D, Jelusic M, Shenoi S (2020) A multinational study of thrombotic microangiopathy in macrophage activation syndrome: a dreadful condition which is likely underrecognized [abstract]. Arthritis Rheumatol 72(Suppl 4)

3. Vasquez-Bonilla WO, Orozco R, Argueta V, Sierra M, Zambrano LI, Munoz-Lara F, Lopez-Molina DS, Arteaga-Livias K, Grimes
Z, Bryce C, Paniz-Mondolfi A, Rodriguez-Morales AJ (2020) A review of the main histopathological findings in coronavirus disease 2019. Hum Pathol. https://doi.org/10.1016/j.humpa th.2020.07.023

4. McGonagle D, O'Donnell JS, Sharif K, Emery P, Bridgewood C (2020) Immune mechanisms of pulmonary intravascular coagulopathy in COVID-19 pneumonia. Lancet Rheumatol 2(7):e437e445. https://doi.org/10.1016/s2665-9913(20)30121-1

5. Webb BJ, Peltan ID, Jensen P, Hoda D, Hunter B, Silver A, Starr N, Buckel W, Grisel N, Hummel E, Snow G, Morris D, Stenehjem E, Srivastava R, Brown SM (2020) Clinical criteria for COVID19-associated hyperinflammatory syndrome: a cohort study. Lancet Rheumatol. https://doi.org/10.1016/s2665-9913(20)30343-x

6. Sinha P, Matthay MA, Calfee CS (2020) Is a "Cytokine Storm" relevant to COVID-19? JAMA Intern Med 180(9):1152-1154. https://doi.org/10.1001/jamainternmed.2020.3313

7. Ackermann M, Verleden SE, Kuehnel M, Haverich A, Welte T, Laenger F, Vanstapel A, Werlein C, Stark H, Tzankov A, Li WW, Li VW, Mentzer SJ, Jonigk D (2020) Pulmonary vascular endothelialitis, thrombosis, and angiogenesis in Covid-19. N Engl J Med 383(2):120-128. https://doi.org/10.1056/NEJMoa2015432

8. Piazza G, Morrow DA (2020) Diagnosis, management, and pathophysiology of arterial and venous thrombosis in COVID19. JAMA. https://doi.org/10.1001/jama.2020.23422

9. Teuwen LA, Geldhof V, Pasut A, Carmeliet P (2020) COVID-19: the vasculature unleashed. Nat Rev Immunol 20(7):389-391. https ://doi.org/10.1038/s41577-020-0343-0

10. Pine AB, Meizlish ML, Goshua G, Chang C-H, Zhang H, Bishai J, Bahel P, Patel A, Gbyli R, Kwan JM, Won CH, Price C, Dela Cruz CS, Halene S, van Dijk D, Hwa J, Lee AI, Chun HJ (2020) Circulating markers of angiogenesis and endotheliopathy in COVID-19. PulmCirc 10(4):2045894020966547. https://doi. org/10.1177/2045894020966547

Publisher's Note Springer Nature remains neutral with regard to jurisdictional claims in published maps and institutional affiliations. 